\section{Microbiological evaluation of sugarcane juice sold at street stands and juice handling conditions in São Carlos, São Paulo, Brazil}

\author{
Avaliação microbiológica de caldo de cana \\ comercializado em ruas e condições de manuseio \\ de manipuladores em São Carlos, São Paulo, Brasil
}

\author{
1 Departamento Morfologia \\ e Patologia, Universidade \\ Federal de São Carlos, \\ São Carlos, Brasil. \\ Correspondence \\ C. W. O. Souza \\ Departamento Morfologia \\ e Patologia, Centro de \\ Ciências Biológicas \\ e da Saúde, Universidade \\ Federal de São Carlos. \\ Rod. Washington Luis, \\ km 235, São Carlos, SP \\ 13565-905, Brasil. \\ clovis@power.ufscar.br
}

\begin{abstract}
Fresh sugarcane juice is sold by street vendors without any heat treatment in São Carlos, São Paulo, Brazil. Twenty-four samples of point-ofsale juice were tested by standard methods to determine heterotrophic bacteria, total and thermo-tolerant coliform counts, Salmonella, and parasites in the juice. 25\% of samples showed poor sanitary conditions, with thermotolerant coliform levels higher than allowed by Brazilian standards. Salmonella spp. and parasites were absent in all samples. Thermo-tolerant coliforms were detected on the hands of $37 \%$ of juice handlers, and heterotrophic bacterial counts reached $2.0 \times 10^{3} \mathrm{cfu} / \mathrm{per}$ hand. Escherichia coli was detected in one hand sample, and no Salmonella spp. was detected. Screening questionnaires were used to interview the vendors, and $62 \%$ of interviewees were either unfamiliar with or failed to adopt adequate hygiene for food handling.
\end{abstract}

Food Handling; Food Contamination; Enterobacteriaceae; Sugarcane
Aline Cristine Garcia Oliveira 1 Antonio Sergio Spano Seixas 1 Cristina Paiva Sousa 1 Clovis Wesley Oliveira Souza 1

\section{Introduction}

Epidemiological data indicate that cross-contamination during food preparation contributes notably to the occurrence of food-borne diseases 1 . To ensure that food is microbiologically safe, both food handlers 2 and the food itself must be monitored on a permanent basis 3 . Commercial production of sugarcane juice consists of a small number of operations, but this critical process can lead to the introduction of microorganisms or the proliferation of those already present. Possible sources of microbial contamination have been identified as (i) unhygienic handling; (ii) the raw material itself; (iii) inadequate cleaning of the sugarcane press, knives, contact surfaces, clothes, and vendors' hands; and (iv) airborne contamination.

This paper used standard microbiological and parasitological methods to evaluate the quality of sugarcane juice, the microbiota on vendors' hands, the handlers' hygiene habits, and conditions under which the beverage was sold in São Carlos, São Paulo, Brazil.

\section{Material and methods}

\section{Survey}

From December 2002 to November 2003, a total of 24 points of sale were analyzed. Sampling 
sites were randomly determined, based on the places where sugarcane juice was sold by street vendors in São Carlos. At each point of sale, one sample of sugarcane juice was taken for microbiological and parasitological analysis and $\mathrm{pH}$ measurement. After free and informed consent, the sanitary conditions of 19 vendors' hands were determined using bacteriological analyses, and questionnaires were used to measure the vendors' knowledge and regular compliance with proper hygiene.

\section{Sample collection}

A total of $300 \mathrm{~mL}$ of freshly extracted sugarcane juice with no lemon added was collected at each site and stored in a sterile plastic bag under aseptic conditions.

\section{Bacteriological analysis of sugarcane juice}

Microbiological analysis included isolation and identification of potential pathogens according to standard procedures for the number of heterotrophic bacteria, most probable number (MPN) of total and thermo-tolerant coliforms, and presence or absence of Salmonella in a $25 \mathrm{~mL}$ aliquot 4,5 .

For heterotrophic bacterial counts, decimal dilutions (10-1-10-4) of the product were made, and aliquots of $100 \mu \mathrm{L}$ were spread on Plate Count Agar (35०C/24-48h).

The MPN of total and thermo-tolerant coliforms was determined, following APHA 4 recommendations. In brief: three serial dilutions ( $1 \mathrm{~mL}, 0.1 \mathrm{~mL}$ and $0.01 \mathrm{~mL}$ ) were inoculated in Lauryl Sulfate Tryptose broth (35ㄷ $/ 24-48 \mathrm{~h})$. Positive tubes (gas formation and turbidity) were seeded in Brilliant Green 2.0\% Lactose

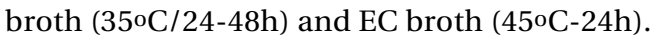

Positive tubes from Escherichia coli broth were streaked on Eosin Methylene Blue Agar. Typical E. coli colonies were stabbed in TSI agar and identified biochemically.

Presence or absence of Salmonella spp. was determined as recommended by APHA 4, and $25 \mathrm{~mL}$ of the sugarcane juice was placed in $225 \mathrm{~mL}$ of peptone buffer water. Aliquots of $1 \mathrm{~mL}$ were transferred to tetrathionate and RappaportVassiliadis broths $\left(35^{\circ} \mathrm{C} / 24 \mathrm{~h}\right.$ and $42^{\circ} \mathrm{C} / 24 \mathrm{~h}$, respectively) and a loopful of each suspension were streaked on SS agar and XLD medium (37oC/24h). Suspected Salmonella colonies were submitted to standard biochemical and serological tests (agglutination tests performed with polyvalent serum).

\section{Bacteriological analysis of hands}

The swab method was used for Salmonella and coliform determination on hands. The swab was moistened in buffered peptone water $(\mathrm{pH}$ : $7.2 \pm 0.2$ ), and microorganisms were removed mechanically. The swab was placed in the same peptone tube and incubated (350C/24-48h), followed by streaking in SS, XLD, and EMB agar. After growth, the typical colonies were identified using EPM-MILI and Simmons Citrate Agar. For heterotrophic counts, hand-printing on Plate Count Agar was used (35 $\left.{ }^{\circ} \mathrm{C} / 24-48 \mathrm{~h}\right)$.

\section{Parasitological analysis}

The sedimentation and concentration method using $200 \mathrm{~mL}$ of sugarcane juice $(7 \mathrm{oC} / 24 \mathrm{~h})$ was used to detect cysts, eggs, and larvae 6,7 in the samples.

\section{Results}

As shown in Table 1, six (25\%) of the 24 sugarcane juice samples displayed inadequate hygienic-sanitary conditions, exhibiting thermotolerant coliforms in higher numbers than allowed by the Brazilian National Health Surveillance Agency (Agência Nacional de Vigilância Sanitária-ANVISA) 5. Samples analyzed in this study had a mean $\mathrm{pH}$ of 4.89 (Table 1).

The heterotrophic bacterial counts in the sugarcane juice showed some variation (1.0x

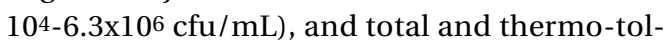
erant coliform counts varied from $<3$ to $>2,400$ MPN/mL (Table 1).

The parasitological results were negative for worms and protozoans in all the juice samples analyzed (Table 1).

Seven samples from vendors' hands (37\%) yielded thermo-tolerant coliforms, and one sample (5.3\%) showed E. coli. Heterotrophic counts on hands varied from $7.8 \times 10^{1}$ to $2.0 \times 10^{3} \mathrm{cfu}$.

According to the questionnaire, $57 \%$ of food workers were unaware of either the importance of maintaining proper hygiene with equipment and utensils or the likelihood of causing a food-borne illness, while $62 \%$ were either unfamiliar with or failed to adopt proper hygienic practices for food handling.

Salmonella spp. was absent in all the sugarcane juice samples. The results also showed absence of Salmonella spp. on the hands of the food handlers. 


\section{Discussion}

According to this study, $25 \%$ of the sugarcane juice samples failed to comply with ANVISA legislation regarding thermo-tolerant coliforms 5 . A study on the quality of food sold in the streets in São Paulo showed similar results, with thermo-tolerant coliforms in $30 \%$ of the samples 8 . Soccol et al. 9, studying sugarcane juice, found high coliform numbers, with $78 \%$ of their samples contaminated. The $\mathrm{pH}$ range of 3.40 to 5.34 , inappropriate for the growth of most pathogens, can cause food-borne diseases.

The heterotrophic bacterial counts in the sugarcane juice showed some variation, as did the total and thermo-tolerant coliform counts. These results probably reflect the inadequate sanitary conditions of sugarcane itself, the equipment, and the water used by handlers to wash their hands.

The parasitological data showed negative results for worms and protozoans in all the samples analyzed.

The data presented here suggest that sugarcane juice could be contaminated microbiologically by factors such as equipment and utensils with inadequate hygienic conditions, utensils left uncovered, trash cans left open and in unsuitable places, and infrequency of hand-washing. Cross-contamination during food preparation has been identified as an important factor associated with food-borne illness 10 . In this survey, the sugarcane press, utensils, and food handlers' hands were not properly washed. The food handlers only used plain water to wash their hands, the press, and working surfaces.

The presence of $E$. coli and other coliform bacteria is generally an indication of fecal contamination of water and food. Seven samples from the hands of food handlers showed the presence of thermo-tolerant coliforms, and in one sample E. coli was present, which could be
Table 1

Microbiological profile of sugarcane juice and Brazilian hygiene standards.

\begin{tabular}{lcc}
\hline Microorganism, group, pH & Brazilian standards $^{\star}$ & Sugarcane juice data \\
\hline Salmonella spp./25mL & Absence & Absence \\
Thermo-tolerant coliforms/mL & $10^{2}$ & $<3$ to $>2,400$ \\
Total coliforms/mL & - & $<3$ to $>2,400$ \\
Heterotrophic bacteria/mL & - & $1,0 \times 10^{4}$ to $6,3 \times 106$ \\
Parasites & - & Absence \\
$\mathrm{pH}$ & - & $4.89 * \star$ \\
\hline
\end{tabular}

* RDC Ruling no. 125 .

** $\mathrm{pH}$ range, 3.40 to 5.34 .

explained by inadequate hand-washing by food workers and the absence of good manufacturing practices. A survey of retail food establishment 11 showed similar results: only $52 \%$ of the food handlers knew how to wash their hands.

In the present study, $57 \%$ of food workers were unfamiliar with the importance of maintaining equipment and utensils in hygienic conditions. Similar results were found in a study on hotdogs 12. Inadequate hygiene was due mainly to lack of knowledge rather than negligence with proper precautions.

In relation to the variation in the heterotrophic counts on hands, it can be assumed that the handlers processed this beverage without washing their hands adequately.

Salmonella spp. was absent from all juice samples and food handlers' hands. However, Bastos et al. 13 found a correlation between coliforms and Salmonella spp.

The best way to reduce such risks is to train the people involved in food-handling 14 . Cleaning procedures for food contact surfaces should be evaluated, and special attention should be given to items used during processing (gloves, baskets, kitchen towels, and hand tools) 15.

\section{Resumo}

O caldo de cana é recém-preparado e comercializado por manipuladores sem tratamento térmico em São Carlos, São Paulo, Brasil. Vinte e quatro amostras da bebida obtidas em condição de consumidor nos pontos de venda foram avaliadas utilizando-se métodos convencionais na determinação de bactérias heterótrofas, contagens de coliformes totais e termo-tolerantes, Salmonella spp. e parasitas. Observou-se que 25\% das amostras apresentaram condições sanitárias insatisfatórias, com níveis de coliformes termo-tolerantes superiores aos permitidos pelos padrões brasileiros. Salmonella spp. e parasitas não foram detectados em nenhuma amostra. Em 37\% das mãos de manipuladores do produto detectou-se coliformes termo-tolerantes e as contagens de organismos heterótrofos atingiu valores de 2,0x103UFC/por mão. Em uma amostra de mão detectou-se a presença de Escherichia coli e ausência de Salmonella spp. Utilizaram-se entrevistas por meio de questionários com os vendedores e 62\% destes não admitiram conhecimento ou adoção de quaisquer práticas higiênico-sanitárias para manipulação de alimentos.

Manipulação de Alimentos; Contaminação de Alimentos; Enterobacteriaceae; Cana-de-Açúcar 


\section{Contributors}

A. C. G. Oliveira and C. W. O. Souza collected the samples and conducted the microbiological analyses. A. S. S. Seixas conducted the parasitological analyses and reviewed the manuscript. C. P. Sousa wrote and corrected the article.

\section{References}

1. Kusumaningrum HD, Asselt ED, Beumer RR, Zwietering $\mathrm{MH}$. A quantitative analysis of cross-contamination of Salmonella and Campylobacter spp. via domestic kitchen surfaces. J Food Prot 2004; 67:1892-903.

2. Costa-Cruz JM, Cardoso MLG, Marques DE. Parasitas intestinais em manipuladores de alimentos de escolas na cidade de Uberlândia, Minas Gerais, Brasil. Rev Inst Med Trop São Paulo 1995; 37:191-6.

3. Arias B, Soto E, Sepúlveda L, Herrera A. Infecciones intestinales por parásitos y/o comensales en manipuladores de alimentos de hospitales del sector norte de Santiago, Chile. Bol Chilen Parasitol 1987; 42:84-6.

4. American Public Health Association. Compendium of Methods for the Microbiological Examination of Foods. Washington DC: American Public Health Association; 1992.

5. Agência Nacional de Vigilância Sanitária. Resolução RDC n. 12, de 12 de janeiro de 2001. Diário Oficial da União 2001; 10 jan.

6. Lutz A. O Schistosomum mansoni e a schistosomose segundo observações feitas no Brasil. Mem Inst Oswaldo Cruz 1919; 11:121-55.

7. Hoffmann WA, Pons JA, Janer JL. The sedimentation-concentration method. J Publ Health 1934; 9:281-98.

8. Torres EAFS, Matté, MH, Matté GR, Morita M, Hanashiro A. Microbiological quality of selected street foods from a restricted area of Sao Paulo city, Brazil. Food Control 2005; 16:439-44.
9. Soccol CR, Schwab A, Katsoka, CE. Avaliação microbiológica do caldo de cana (garapa) na cidade de Curitiba. Bol Centro Pesqui Process Aliment 1990; 8:116-25.

10. Wanyenya I, Muyanja C, Nasinyama GW. Kitchen practices used in handling broiler chickens and survival of Campylobacter spp. on cutting surfaces in Kampala, Uganda. J Food Prot 2004; 67:1957-60.

11. Allwood PB, Jenkins T, Paulus C, Johnson L, Hedberg CW. Hand washing compliance among retail food establishment workers in Minnesota. J Food Prot 2004; 12:2825-8.

12. Lucca A, Torres EAFS. Condições de higiene de "cachorro-quente" comercializado em vias públicas. Rev Saúde Pública 2002; 36:350-2.

13. Bastos MSR, Feitosa T, Borges MF, Oliveira MEB, Azevedo EH. Avaliação microbiológica das mãos de manipuladores de polpa de fruta congelada. Hig Aliment 2002; 16:55-7.

14. Gilling S, Taylor EA, Kane K, Taylor JZ. Successful hazard analysis critical control point implementation in the United Kingdom: understanding the barriers through the use of a behavioral adherence model. J Food Prot 2001; 64:710-5.

15. Souza EL, Silva BHC, Sousa CP. Manipuladores como causas potenciais de contaminação de alimento enteral. Infarma 2003; 15:71-3.

Submitted on $21 /$ Jun/2005

Final version resubmitted on 14/Dec/2005

Approved on 19/Dec/2005 